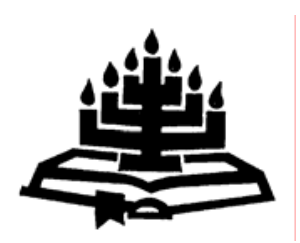

\title{
Hugo du Plessis' theology of mission as influenced by missiological debates in ecumenical circles
}

\author{
T.D. Mashau \\ School for Ecclesiastical Sciences \\ Potchefstroom Campus \\ North-West University \\ POTCHEFSTROOM \\ E-mail: Derrick.Mashau@nwu.ac.za
}

\begin{abstract}
Hugo du Plessis' theology of mission as influenced by missiological debates in ecumenical circles
\end{abstract}

The quest to understand the church's missionary calling will remain a significant exercise in the life of the church of every age. Transformation in the world context compels the church to rethink its missionary calling and to strive towards a theology of mission that will respond positively towards the changing context. Hugo du Plessis lived and worked in the 20th century as the first missionary and missiologist of the Reformed Churches in South Africa (GKSA). It is the thesis of this article that Hugo du Plessis' theology of mission, which had great impact on how the GKSA responded to the challenges of the day, was informed and shaped by missiological debates which took place within ecumenical circles.

\section{Opsomming}

Hugo du Plessis se teologie oor sending soos beïnvloed deur missiologiese debatte in ekumeniese kringe

Die soeke om die kerk se roeping ten opsigte van sendingwerk te verstaan, bly 'n belangrike taak van die kerk deur alle tye. Transformasie in die wêreld, dwing die kerk tot nadenke oor sy roeping ten opsigte van sendingwerk sowel as die strewe na 'n teologie van sendingwerk wat positief sal presenteer binne die veranderende konteks. Hugo du Plessis het in die 20ste eeu geleef en gewerk as die eerste sendeling van die Gereformeerde Kerke in Suid-Afrika (GKSA). Die kern van hierdie artikel dui aan hoedat Hugo du Plessis se teologie ten opsigte 
van sendingwerk verander is en vorm aangeneem het deur die missiologiese debatte wat in ekumeniese kringe plaasgevind het. Du Plessis se sendingteologie het 'n groot impak gehad op die wyse van die GKSA se reaksie teenoor die uitdagings van destyds.

\section{Introduction}

Hugo du Plessis was born on 22 March 1902, in Burgersdorp in the Cape Colony. He is the son of Prof. J.A. du Plessis and Laurika Postma. He was the grandchild of a well-known figure in the history of the Gereformeerde Kerk in Suid-Afrika (GKSA) and the Theological School in Potchefstroom, Prof. S. du Toit (Van der Vyver, 1958:458). Hugo du Plessis completed his ministerial studies in 1927 and was admitted to ministry during the Particular Synod meeting of Transvaal on its meeting held on 22 January 1928 in Nylstroom. He was then called by the Reformed Church Pretoria to be a missionary among the Vhavenda-speaking people in the Soutpansberg 1 where he served until 1950.

In 1950, Rev. Du Plessis accepted a call to serve in the Witwatersrand, and specifically in Soweto (Mashau, 2004:17). He served as a missionary until 1955 when he became the first lecturer to train black ministers of the Word at Moroka and later Dube. It was only in 1959, during the 100 years celebration of the GKSA's existence, when Missiology was introduced as a theological discipline in the Theological School of Potchefstroom, that Du Plessis was appointed as the first chair and professor of Missiology. He served in this capacity for thirteen years until 1971 when he died (Van der Walt, 1976:47). It is the presupposition of this article that Du Plessis' theology of mission was shaped by the missiological debates during his time, hence the need to investigate those debates.

\section{Mission and missiology in ecumenical circles}

The period between 1914 and 1938 marked a new era in the history of mission. The period from 1938 onwards brought about major developments regarding the science of mission (missiology) in many respects. The conference of mission in Tambaran (1938), just on the

1 His missionary tasks focused mainly in Uniondale (where he resided), Molietsieskop, and Siloam, which later became the main missionary station (Jooste, 1976:13,16). 
eve of World War II, brought life to missiology. The conference dealt with the issue on "Rethinking missions". Mission of the church had to come into real terms with the world crisis or real world conditions. The nature of missiology, the way in which it should be understood, its foundation and its development became the centre of the debate. Consequently, the following developments were noticeable:

\subsection{The church and mission}

The question on the relationship between the church and mission remained at the heart of the theological debate for many centuries. There was a sharp distinction between the two before World War II. There are basically three factors that Du Plessis noted in this regard. Mission as done by mission societies, the collegialistic and pietistic church, is concept or understanding that accompanied it. As a result of this differentiation, there was no clear church relation between the old and the young church (Du Plessis, 1960a:4).

Developments that took place during the post World War II era included among others the following:

- The independency of the young church was fully recognised in the mission conference held in Whitby (1947). It was during this conference that the relation between the old and the young church was defined as "partnership in obedience". In this relationship, the old churches were still obligated to offer assistance to the young churches as long as they needed it (Du Plessis, 1970:146).

- Whilst it was agreed upon that the young church have a place in the universal church of Christ, the indigenous aspects were fully emphasised. Liturgical forms and related issues should not be the blue-print of the Western churches, but the spiritual heritage of the nation and country where the young churches are planted should be taken into account (Du Plessis, 1970:157).

- There was also an intensive debate on the ecumenical front regarding the nature, task and purpose of mission and the relationship between the church and mission. To elucidate this, Du Plessis reflected on the works of J. Dürr and J.C. Hoekendijk. On the one hand Dürr pointed out that the agent of mission cannot be the missionary society, but the church. The church as a new community wherein Christ is the head, is an independent church as compared to the old church. The missionary calling of this church is service to the up-building of the particular church, 
and Dürr lays emphasis on the Christological and eschatological aspects of the church. Hoekendijk on the other hand, maintained a comprehensive approach in which man in his totality should be influenced in a Christian manner (Du Plessis, 1970:148).

- The mission conference in Willingen (1952) also addressed the issue on "The missionary obligation of the church". The conference agreed that mission is primarily the mission of the Triune God. God sends forth the church (Du Plessis, 1970:151) to carry out his work to the ends of time. Within the body of Christ all members are called to serve in oneness, and as a result mission is the task of the whole church of all times to the whole world.

- The mission conference held in Newbigin (1963) addressed the issue on the Trinitarian foundation of mission and missiology further. They dealt specifically with "The relevance of trinitarian doctrine for today's mission” (Du Plessis, 1970:153).

\subsection{Mission and eschatology}

Theologians like O. Cullmann, W. Freytag and K. Hartenstein developed the theological foundation of missiology from an eschatological perspective. The coming of Christ and his coming for the second time is seen in terms of the history of salvation as qualifying the coming of the kingdom of God as a present reality and yet to come. According to Freytag and Hartenstein: "Deur sending berei die verhoogde Christus sy wederkoms voor, want Hy het self gesê: Die evangelie moet eers aan alle volke verkondig word en dan sal die einde kom (Matth. 24:14, Mrk. 13:10)" (Du Plessis, 1970:154). Through the mission of the church something of the future coming kingdom of God is realised. Theologians also dealt with the future of Israel and the question on the relation between the Old Testament people of God and the New Testament people of God.

\subsection{The principle of independence in mission}

The question of the self-determination of the young church became crucial in the debate on the relation between church and mission. A number of aspects are noticeable in this debate:

- Despite emphasis on the self-determination of the young churches they always remained photocopies of the Western churches that planted them. They remained spiritual colonies of the West in terms of their structures, style of expression, liturgy and so forth. 
- Younger churches should be rooted in their own countries and everything should be dealt with in an indigenous way in order to accommodate the spiritual heritage of the indigenous people.

- Relevancy of the church's proclamation should always be taken into consideration. The church should always guard against the danger of syncretism.

- The nature of the church, the truth of the Word of God and the historical continuity with the universal church of Christ should never be compromised when the young churches develop their liturgy, church order and creeds. Biblical principles remain the same under all circumstances, hence they may be applied differently varying from one context to another.

\subsection{Mission approach}

Development in this regard does not entail the confrontation of the non-Christian religions, but the missionary approach through "communication and so-called comprehensive approach". In his discussion, Hugo du Plessis touches on the following:

\section{- Communication}

In the encounter between the missionary and the object(s) of mission, communication is a very important element. It entails the notion of dialogue and it is the key to success or failure in this regard. Even in reformed circles where they hold dear to the teaching of election, proclamation of the Word of God to all nonbelievers remains imperative. All non-believers should be perceived as potential elects of God (Du Plessis, 1970:163). Regarding mission approach through communication the following can be remarked:

- Language remains an integral part of communication. Language entails not only the translation of the Christian faith, but also the verbal and non-verbal ways of communication.

- The apostolate theology emphasises the aspects of kerugma, koinonia and diakonia in communicating the message of the gospel. "Hierdie drie is onafskeidelik aan mekaar verbind. As een daarvan verwaarloos word, loop alles verkeerd" (Du Plessis, 1970:163, 164).

- The fellowship (koinonia) becomes a living testimony of the truth and power of the gospel. 
- All members of the church should strive to become agents of God in proclaiming the gospel wherever they are; they must be a light to the world in all spheres of life.

- Humility must accompany the Christian way of communication in mission, especially when dealing with the adherents of Islam.

- Dialogue is also highly emphasised. According to the results of the International Mission Conference (1963) in Mexico: "Die doel in elke dialoog moet wees om betrokke te wees in die dialoog van God met die mense en om ons gespreksgenoot en onsself te beweeg om te luister na wat God in Christus aan ons openbaar en om Hom te antwoord" (Du Plessis, 1970:164).

\section{- The comprehensive approach}

The comprehensive approach started to receive prominence in ecumenical circles after its introduction at the International Missions Conference in Jerusalem in 1928 (Bavinck, 1960:108). This missionary approach entails that man should be approached in a holistic way (Du Plessis, 1970:165).

\subsection{The cosmic meaning of Christ and mission}

The cosmic significance of Christ also became a most debated issue in the ecumenical arena. During the World Council of Churches held in New Delhi in 1962, it was agreed upon that Christ is not only the head of the church but also of the whole world. According to texts like Ephesians 1:10, 23, Colossians 1:15-20 and 1 Corinthians 5:19 it has been concluded that it is God's purpose to bring everything into a harmonious unity (oneness) under the head Jesus Christ, the One who reconciled the whole world with God (1 Cor. 5:19). In New Delhi, it was agreed upon that the Christian must always recognise that Jesus Christ is the Lord of history and $\mathrm{He}$ is at work every day in every nation of the world in spite of, and through the ambiguous political, economic or social structures and actions in any given country. The new life of a new humanity in Christ should be preached to the whole world (Du Plessis, 1970:169).

\subsection{The relation between the Christian faith and the non- Christian religions}

Over and against the radical antithesis approach to non-Christian religions, the new development brought about a synthesis approach. The encounter with non-Christian religions can never be avoided, hence the nature, place and task of elenctics should enable missio- 
naries and missiologists to deal with it. Elenctics, according to Bavinck, should be considered part of missiology (Du Plessis, 1970:135). As a result, the theology of religion should find its basis in theology, and should also find the theological interpretation therein.

It should be noted with great interest that Du Plessis was not a passive missionary and missiologist. He participated vigorously in the debates about mission and missiology as they took place within the ecumenical arena. As noted above, Du Plessis engaged his contemporaries and this has had a great impact on his theology of mission. The impact that ecumenical debates had on Du Plessis' theology of mission will become clear as we next outline his theology.

\section{Du Plessis' theology of mission as influenced by the ecumenical debates of his time}

\subsection{The concept of mission}

The quest to redefine mission and evangelism featured mainly in the theological debates at the end of the first half to the beginning of the second half of the 20th century. The words mission and evangelism were defined and used in different ways. The escalation varied from one school of thought to another. There are those who define mission and evangelism as synonyms that can be used interchangeably with the word witness. Some defined mission as something that the church does in the far-away pagan countries and evangelism as something done within your own people who are no longer interested in church matters (Bosch, 1993:11, 12). In the circles of the World Council of Churches, mission was defined to encompass everything that the church does. Lesslie Newbigin defined the concept mission as referring to everything that the Church is sent to do into the world - preaching of the gospel, healing the sick, caring for the poor, teaching the children, improving international and interracial relations and attacking injustice (Hoekstra, 1979:27). If everything that the church does in the world is mission, what then is mission?

In line with the great commission in Matthew 28:18-20, Du Plessis (1963:74) defined mission as "crossing the barriers". This was more in line with the apostolate theology of Hoekendijk who laid too much emphasis on the missionary work of the church. The church was seen more and more as a witnessing community, which is always proclaiming the gospel of the kingdom of God. Du Plessis' under- 
standing of "crossing the barriers" entailed not only the objective preaching of the Word, but also the addressing of the specific needs of the objects of mission, as vindicated in their particular context. His definition was totally in line with that of Bishop Stephen Neill who defined mission as the intentional crossing of barriers from the Church to the non-church in word and deed for the sake of the proclamation of the gospel. Bosch (1993:17) echoed the same when he defined mission as a broader term (but not all-inclusive) that comprises more than the proclamation of the gospel. Mission is therefore the symbol of the Church moving towards the world. That is why Hoekendijk defined mission as proclamation, fellowship, and service - kerygma, koinonia, and diakonia. He maintains that all these three aspects should be integrated in the church's work of evangelism and mission. Should the three be integrated then the church's methods for mission are justifiable (Hoekendijk, 1950:171; cf. McGavran, 1983:17). Meiring (1984:36) added the fourth aspect/rubric of the public worship service of God (leitourgia). He considers this four rubrics as a holistic approach to mission that encompasses all other activities of the church.

It should, however, be emphasised at this stage that not everything that the church does can be defined as mission, but whatever the church does should entail the missionary dimension. Bishop Stephen Neill correctly remarked that "if everything is mission, then nothing is mission". When the church gathers on Sunday their intention is to worship God, but they need to organise their service in such a way that they also draw visitors and observers attending their worshipping service to Christ. Whenever the church takes care of the poor their intention is to engage in the ministry of mercy, but if undue emphasis is given to diakonia then it becomes only a humanitarian deed. Hoekendijk (1950:172) emphasised that one cannot render real service if he deprives man of the kerygma and leaves him outside the koinonia, and of course the leitourgia.

Furthermore, Du Plessis was of the opinion that mission among Africans should be done mainly by whites. He maintained that whites should not only preach the gospel to blacks, but they should also identify their needs, extend a hand of friendship, and cooperate with them in addressing those needs (Du Plessis, 1963b:74). In this regard he concurred with the traditional understanding of evangelism and mission. On one hand evangelism was viewed as something to be done among your own people, and on the other hand mission was to be done among the heathens in the far away countries (Bosch, 1993:12). It should be noted that 
evangelism is the proclamation of the good news about Christ and is the integral part of mission. It is the essential dimension of mission without which the church's mission is reduced to mere humanitarian deeds.

\subsection{The purpose of mission}

The 1950s and 1960s were also characterised by theological debates surrounding the question of the purpose for Christian mission. Already in 1942, Walter Freytag supported the idea of doing mission with the end of the world in mind. He appealed to such passages as Mark 13:10 and the fact that "the command to world mission" was the last mandate that Jesus gave to his disciples (Freytag, 1959:148). In the early 1950s, Freytag identified the four schools of thought on this topic. He maintains that there are those who engaged in missionary work for the salvation of individuals (pietistic approach), church planting, humanisation, and eschatological drive - hastening the end of the world (Freytag, 1950:154156).

It was only in the late 1960s that many theologians and churches focused on humanisation as the real goal of mission. The notion of "the Church for others" as propagated by Hoekendijk encouraged many in the church to seek for social justice and development of the poor. During the World Council of Churches at Uppsala (1968) humanisation was lifted up as the goal of mission and emphasis was put upon the horizontal rather than upon the vertical dimension of the gospel. They wanted to attend primarily to the plight of the poor, the hungry, the exploited, the powerless, and the voices of the minorities - youth and women, victims of racism, the imprisoned and the tortured. Those passages in the Bible dealing with God's concern for the poor and liberation took on vast new meanings with their own implications about our understanding of God and his intent for the world (Hoekstra, 1979:21, 69).

Du Plessis did not agree fully with his contemporaries when they mentioned that the purpose of mission was to create a new humanity in Christ. The Biblical passages that were used to support humanisation as the goal of mission were selectively chosen. Du Plessis maintained that mission is first and foremost not about man, but the missionary God and salvation in and through Christ should be preached to bring about hope to the fallen humanity (Du Plessis, 1969:281). 
Du Plessis $(1965 a: 268,269)$ summarised the purpose of mission in the following words:

Die werk van die Heilige Gees wat Hy deur die gemeente doen om so die werklikheid van die koninkryk van God asook 'n weerspieëling van die bestemming van die mensheid en die kosmos te openbaar deur die prediking, planting van kerke en die lewe van gelowiges, om so die wêreld tot 'n beslissing te bring t.o.v. die keuse vir of teen Christus en vir of teen die bestemming wat God vir alles stel.

There are five aspects involved in his understanding of the purpose of mission, namely the following:

\subsubsection{The obedience-motif}

The motive of obedience is one of the central forms in which the church of God is motivated to bring about glory to God by being a missionary church. According to Van den Berg (1956:177), the church stood under the marching orders of Christ, given after his resurrection in the "great commission" of Matthew 28:19. This we accept as an authentic testimony of the words spoken by our Lord Himself in the period before his ascension. In line with Van den Berg, Du Plessis sees this command as one of the motives for the church to engage in missionary work. He calls this the obediencemotif, in that Christ gave the command to his servants to fulfil in obedience to Him. The obedience-motif is based on Jesus Christ's words in John 20: 21 "... Peace be with you! As the Father has sent me, I am sending you" (Du Plessis, 1965a:266).

\subsubsection{The mission of Christ}

From the words of Christ in John 20:21, it is clear that He was sent by the Father to set the world free and to bring everything to its true destination. He does this to bring everything to perfection in Him. This in itself becomes the motif for the church to do mission in that they call upon men to believe in Christ and to follow the way to true human destination (Du Plessis, 1965a:266).

\subsubsection{The purpose of the mission of Christ}

The purpose of the mission of Christ in the world is also the purpose of the church's mission to the world. As regarding the purpose of Christ's mission to the world, Du Plessis (1965a:267) remarked that:

Christus se sending beoog die verlossing en herskepping van die mensheid en die ganse kosmos, die verlossing en her- 
skepping van die menslike lewe, die gemeenskapslewe, die menslike arbeid, kultuur, wetenskap, e.d.m. die verlossing en herskepping van die hele mens na siel en liggaam.

In this regard, Du Plessis is of the opinion that Christ's mission is the restoration of the fallen humanity by reconciling humanity to God in Christ. The restoration entails the re-creation of the new humanity of God's people from among all the nations of the world in Christ by the power of the Holy Spirit. The church, which is in communion with Christ, should by virtue of their faith in Him and communion with Him, engage in his missionary activities (Du Plessis, 1965a:267).

\subsubsection{Witnessing-motif}

The church does mission work in order to witness the deeds of God, those that $\mathrm{He}$ did and those that $\mathrm{He}$ is still doing today. The church is thus the instrument in the hands of God, bearing testimony to the wonderful works of the Triune God in Christ, that is: creation of everything, reconciliation, salvation, and recreation in Christ by the work of the Holy Spirit (Du Plessis, 1965a:267).

\subsubsection{Kingdom-motif}

The kingdom-motif is imperative in that mission does not only entail the renewal of fallen humanity in Christ, but it is also the purpose of God with regard to the destination of his entire creation. He aims to bring the whole of creation, including humanity, under the Lordship of Christ. The church should witness the coming kingdom of God through preaching, church planting, and through the living faith in Christ (Du Plessis, 1965a:268).

The kingdom-motif entails in itself the eschatological foundation of mission in that the kingdom of God will be fully realised in the second coming of Christ. It is asserted that the end of the world will come into being when the missionary mandate of the church has been fulfilled (see Du Plessis, 1965b:238; cf. Matt. 24:14; Mark 13:10). Peter Beyerhaus echoed this notion of the Kingdom-motif as the goal for the Christian mission over and against humanisation. He maintained that the motive and goal of world mission is the Kingdom of God (Beyerhaus, 1971:11).

Du Plessis succeeded in outlining the fact that the church should engage in the missionary task in obedience to their risen Lord, who instructed them to proclaim the gospel of the Kingdom in order to make disciples from among peoples of the entire universe. The proclamation of the gospel, making of disciples, mobilisation and 
integral growth and development remains central in the advancement of the Kingdom of God.

\subsection{The content of mission}

When it comes to the content of mission, Du Plessis maintains that mission should address the spiritual and physical needs of the fallen humanity.

\subsubsection{The Word of God should be proclaimed}

Man, in his context, should be confronted with the living Word of God. It must be proclaimed in such a way that it addresses man in all spheres of life. It was Du Plessis' thesis that the church should not shy away from verbal communication of the Word of God (Du Plessis, 1966:13).

\subsubsection{Spiritual needs of humanity}

The spiritual needs of humanity, the needs in human life, were brought about by the fall of man to sin. The communion of man with God was broken as a result of sin. Christ was sent to restore this relationship and to re-integrate the creation in a harmonious unity with Himself (see Du Plessis, 1960b:69).

The proclamation of the Word of God in mission should therefore entail the following aspect:

- Recreation of the fallen humanity through salvation in Christ, as applied by the work of the Holy Spirit. ${ }^{2}$ God, reconciles Himself with fallen humanity, and creates a new humanity from the believing people from among all the nations (see Du Plessis, 1963b:69; cf. Matt. 28:19).

\subsubsection{Physical needs of humanity}

The proclamation of the Word of God should bring hope for the specific context ${ }^{3}$ of the people addressed. Some of the physical needs of humanity, as highlighted by Du Plessis, are:

2 This is the redemptive work of God, of which Du Plessis (1963b:69) remarked that: "The mystery of it, partly revealed in the pouring out of the Holy Ghost, is the unity of Jew and non-Jew in Him, and only in Him, the glorified Son and Head of the new humanity which is His body."

3 Compare with Luke 4:18-19 "The Spirit of the Lord is on me, because He has anointed me to preach good news to the poor. He has sent me to proclaim 
- The socio-economic and political imbalances of humanity (see Du Plessis, 1963b:64).

- Fear of the destruction of humanity in the threatening Third World War (see Du Plessis, 1963b:65).

Du Plessis attended to this issue on "word and deed", with a special emphasis on the justice for the poor and the oppressed, because it occupied the central place in the international arena in the 1950s and 1960s. In ecumenical circles, many thought it was time for the First World countries to engage in development programmes in order to offer deaconal assistance to the churches in the Third World.

Visser 't Hooft, die vorige sekretaris van die Wêreldraad, het gesê dit moet vir ons duidelik wees dat die lidmate wat hulle verantwoordelikheid vir die noodlydendes in ander lande prakties loën, net so skuldig staan as ketters wat een of ander geloofwaarheid verwerp (Du Plessis, 1969:275).

Mission did not only take the form of the ministry of the Word, but also educational, medical, socio-economic, and political dimensions were catered for.

The proclamation of the gospel through "word and deed" reminds us that one of the basic aspects of mission theology has to do with the relation of the Bible to missionary theory and practice. Du Plessis succeeded in propagating the balance between theory and praxis, and also the balance between gospel proclamation in words and deeds. In this regard, he contributed a great deal towards a relevant mission and missiology in that the church of all ages will always be reminded that all development programmes that are not accompanied by the love of God in Christ as proclaimed in the gospel of the kingdom remain humanitarian acts - which cannot be distinguished from what other governmental and non-governmental organisations do to respond to human needs of their time. The church should always make people aware that it is engaging itself in the development programmes because they are caught by the love of Christ in such a way that they are compelled to reach out in love and for Christ to fellow human beings. 


\subsection{The agent of mission}

There are two concepts that feature prominently in Du Plessis' discussions of mission, namely Missio Dei and Missio Ecclesiae.

\subsubsection{Missio Dei}

The concept missio Dei has been used increasingly in missiological debates and literature in the twentieth century. It refers to the mission of God. In this century where mission developed missio Dei was more and more in the direction toward a theocentric point of view in thoroughgoing Trinitarian perspective (Anderson, 1961:15). Formulations varied from culture-centered, man-centered, revelation-centered, eschatology-centered, kingdom-centered, Biblecentered, Church-centered and Christ-centered points of view.

While all of these attempts have stressed various aspects of Christian doctrine that are essential for the missionary enterprise, it seems that when any one of them has been made the central point of focus and orientation for theology of mission, it has proven inadequate for the task, tending to narrow the scope of mission and causing it to go astray (Anderson, 1961:15).

Abraham Kuyper was one of the first theologians to point this out explicitly. The missio Dei concept first surfaced clearly at the Willingen conference of the IMC in 1952 (Saayman, 1984:15). Karl Hartenstein was following in the footsteps of Karl Barth and wanted to protect mission against secularisation and horizontalisation, and to reserve it exclusively for God. Karl Hartenstein introduced the concept missio Dei in his Theologische Besinnung in order to place mission within the widest possible framework of the Heilsgeschichte and God's plan of salvation (Rosin, 1972:23).

The classical teaching that mission is primarily God's, received a serious recognition in this conference. It was the intention of this conference to re-emphasise that the church is only an instrument in the hands of God to bring forth his kingdom. This conference succeeded in producing a Trinitarian approach to the theology of mission. God was correctly seen as the missionary God (Bosch, 1992:392; cf. Glasser, 1983:91; Rosin, 1972:6).

Hugo du Plessis participated in this debate by clearly pointing at God as the subject of mission. He articulated without doubt that neither the church nor any other human agent could ever be considered the author or bearer of mission. Mission is Trinitarian in nature and character. In actual fact, Du Plessis perceived the Triune 
God as a missionary God - missionary in that the Father sent his Son, Jesus, to be the redeemer of man and the Mediator between God and man. The Father and the Son sent the Spirit to apply the redemptive work of Christ and to assemble the church of God in the entire universe (Du Plessis, 1965b:231; cf. Kritzinger, et.al., 1984: 41).

Mission is God giving up himself, his becoming man, his laying aside of his divine prerogatives and taking our humanity, his moving into the world, in his Son and Spirit. It is thus clear that mission has its origin in the heart of God. The ground of mission is God's agape (love) or his charis (mercy-love) (1 John 4:9). Du Plessis' contemporaries echoed the same sentiments at a later stage (Newbigin, 1978:20; cf. Bosch, 1993:240). It is therefore well articulated that in missio Dei, God becomes not only the Sender, but also simultaneously the One who is sent.

\subsubsection{Missio ecclesiae}

The missio Dei concept has direct implications for the missio ecclesiae. Theologians and churches were now able to change from the ecclesiocentric view of mission. They could define the right place of the church in the missio Dei. They returned to the source of the missionary nature of the church. With regard to the involvement of the church in mission, Du Plessis (1942:2) remarked that it pleased God to make use of the church to bring about the ministry of the Word to those who are still outside his covenant. Therefore, missio ecclesiae is derived from the missio Dei. The missio Dei does not exclude the missio ecclesiae as also noted by Kritzinger et al. (1984:41).

According to Du Plessis, the church is the only institution to which God entrusted the mandate to engage in missionary activities. Du Plessis saw this as acts of grace on the side of God, when He, in his free will, chose to work with the church to advance his missionary activities. The church is, therefore, privileged to participate in the mission of the Triune God. Du Plessis sees the church as the new witnessing community. The indwelling of the Holy Spirit in his church since Pentecost brought about this new dimension in the life of the church. Du Plessis (1959:174) is of the opinion that the church can only be the true church of Christ if it does not neglect its missionary calling, to be God's missionary people.

Du Plessis' contribution remains relevant also for the church in postmodern era. When the church engages itself in the missionary 
task, members will always be comforted, encouraged and strengthened to know that they are just instruments in the hands of the missionary God to fulfil his task on earth. The church can therefore not afford the luxury of inward looking and become an ingrown church. It must participate fully, utilizing all individual charismas given to them by the risen Lord through the work of the Holy Spirit, in the mission of God. It must do so with a clear conscience that it is an instrument to accomplish God's mission in the world for the advancement of his Kingdom. The church is therefore not the end in itself, in mission it becomes an obedient servant of the missionary God.

\subsection{The objects of mission}

All the people from all the nations of the world are the objects of mission (Du Plessis, 1965b:238; cf. Matt. 28:19; Luke 24:47). During the life span of Du Plessis, the West viewed Africa in its darkness and other Third World countries, as mission fields. As a result of the process of the de-Christianisation and spiritual decline in the West, the Christian West also provides opportunity for the church to reach out. That is why the World Council of Churches at Mexico City (1963) focused mainly on mission to the six continents of the world. Through Christ, God creates a new humanity of his believers from among people of all nations of the world (Du Plessis, 1959:175). This is in line with the spirit adopted in Mexico City where mission was directed to six continents with the local church being encouraged to witness to:

- men of other faiths;

- men in secular world; and

- men within and in the neighbourhoods of the local church.

It should be noted at this stage that already during the twentieth century the mission frontier was changing drastically from the traditional understanding of geographical, racial, language and cultural to that of belief and unbelief (Bassham, 1979:65).

\subsection{The context of mission}

According to Du Plessis, the entire world should be viewed as the mission field of the church. The world' spiritual and physical needs should be addressed. There is a need for the global context to be highlighted. Both its spiritual and physical needs are of uttermost importance. The following needs and complexities can be identified: 
- Population growth

- Religious plurality and modern ideologies

- Universality and changes in world scenes

- Participation of African churches in world mission

- Western countries becoming mission fields

- Socio-economic-political imbalances (poverty is increasing)

- Race relations (cultural barriers)

- Threats for the continued existence of humanity

- Nominal Christianity

- Urbanisation

In short, the world in its spiritual and physical needs provides the church, in its missionary endeavours, with ample opportunities and challenges. Therefore, the church of the Lord everywhere in the universe should engage itself in mission without any excuse. The world wide challenges, as highlighted above, are still very much part of the 21st century (Greenway, 1999:3-8).

\subsection{The methods of mission}

\subsubsection{The missionary - an ordained minister of the Word}

Du Plessis maintains that a person who serves as a missionary should be an office-bearer who is called by God and sent out by the church solely for proclamation of the Word among the unbelievers (Du Plessis, 1942:2). In his theology, Du Plessis failed to expand more on the ministry of the laity. He still maintained the traditional understanding of a church where the clericals are sought to be there to minister to the laity, and the laity are there to be ministered to. In this regard he did not reflect adequately on the prophetic, priestly and kingly offices of believers because this would have enabled him to see the participation of all members of the church in the church's missionary task, not only by finances.

The church should be structured in such a manner that the individual members of the church, clerics and laity alike, should join hands in their service, as the body of Christ, to serve God, one another and the world. Kritzinger et al. (1984:10) correctly noted that the mission of the church, as also outlined in Ephesians 4:11, depends primarily 
on its total membership. All members of the church should use their charismata to be of service to God and the body of Christ with the intention to draw the outsiders to Christ. Already in 1938 at Madras this point was clearly articulated.

According to Tambaram, missionary activity is not simply the task of a small number of people who have been seized by the idea; it is the task of the Church as whole (Anderson, 1956:21).

\subsubsection{The preaching of the Word}

The preaching of the Word has been a central issue in the calling of the church of Christ to the heathens. Du Plessis maintains that the Word of God should be proclaimed in such a way that it does not ignore the context of the people addressed. This is very clear in the following words: "Christianity throughout the world is called by God to continuously protest against all injustice and it must make its prophetic witness heard against all forms of racial discrimination and warfare" (Du Plessis, 1960b:64). When the Word of God is preached, God, through the work of the Holy Spirit, works the saving faith in the hearts of the heathens. It pleased God to use his church in the preaching of the Word, because faith results from the hearing of the Word (see Du Plessis, 1942:2; cf. Rom. 10:10-15).

\subsubsection{Training of the converts}

Du Plessis maintains that those who are converted to the Christian faith should be trained before they are baptised. They should be trained to know the Word of God and to be able to lead a Christian life (Du Plessis, 1942:2). He maintained that the training of the converts should take not less than two years. Du Plessis (1942:2) gives the following reasons for such a point of view:

Om iemand sommer na geloofsbelydenis te doop, is dopers en oppervlakkig.

Nie alleen moet die geloof deur die verkondiging van die Woord gewek word nie, maar dit moet ook daardeur versterk word.

Die Christene moet ook self leer om die Woord te lees; alleen dan kan hulle opgebou word in hul geloof.

Du Plessis' contribution in this regard is still greatly valued by the church today. Training of the new converts is very much part of the missionary mandate in Matthew 28:16-20. Jesus instructed his disciples not only to make disciples, but also to instruct those who are incorporated in his body through baptism to be instructed in 
order for them to lead a new life by obeying Christ's instructions. The number of years are, however, no longer applicable in this generation because many people are able to read and write on their own. Through the publications of the Christian literature and catechetical instruction books, which are accessible to many converts also in the rural areas, many people get accustomed with Christian teachings in a short time-span. Small groups and Bible study teams, seminars and conferences also provide better opportunities for instruction and spiritual growth.

\subsubsection{Churches must be planted}

Du Plessis (1942:3) maintained that the goal of the church's mission is not only salvation of individuals, but also to plant churches that would become independent, maintain themselves and also be organised in ecclesiastical assemblies of their own, i.e. own classis and own synod assemblies.

Du Plessis' insistence on the planting of the indigenous churches was highly influenced by the ecclesiology of his time. Many theologians viewed mission as a movement of a church to a church with emphasis on the three-selves as propagated by Venn and Anderson in the nineteenth century. The principles of "self-support, selfgovernment, self-propagation" were ideal to his mission. His quest for contextualisation was successful in some respects, but the idea of indigenous churches that gather in the ecclesiastical assemblies of their own was highly influenced by the context of separate development and the system of apartheid of his time. He did not propagate for the "pilgrim principle" that draws the newly founded church in the direction of the universals of faith, rooted in obedience to Christ and the Scriptures as worked out and guided by the Holy Spirit. Accordingly, the indigenous people were pressured into independence and isolation so that they conform to their own cultural surroundings at the price of detachment from the universal church (Walls, 1982:97-99).

Church planting as the purpose of mission will remain ideal for years to come, but yearning for numerical growth changes the whole complexion of the church's mission to the world. Churches planted should not only become independent, but also become God's missionary people who join hands in serving God and one another with the intention to win many people to Christ and also network with the church of God in other parts of the world (ecumenical network). The pilgrim principle as outlined in John 17:13-19 also becomes theirs such that they join hands with other members of the body of 
Christ from all peoples of the world in witnessing for Christ to the ends of the world until his second coming.

The pilgrim principle exposes the weakness in the three-self formula. The three-self formula is a very narrow, shallow, and selfcentred concept in mission. Local congregations are much more than money, administration, and converts. As a provisional sign of the Kingdom they are much more than cultural contextualisation, or indigenisation of the gospel. Though these issues are important, they are only part of a much larger whole that involves the rule of Christ in the world and uniquely in the church through its local missionary communities. This kind of understanding brings about a paradigm shift in the life of the local church. Instead of becoming inward looking and self-serving, the church becomes a servant of God that properly reflect his Kingdom that seeks to bring the whole life under the Lordship of Christ. Denkema (1995:83) correctly asserts that the missionary congregations must have structures and an administrative system that explodes outward into the world on the way to the coming Kingdom of God.

For the sending church to succeed in planting churches as highlighted above, Du Plessis maintains that the following principles must be adhered to:

\section{- Racial identity must be maintained}

The national political and religious developments of universality and nationalism, and ecumenicity and independence respectively, had a great impact on Du Plessis' approach to mission. Along these lines, he developed an understanding of unity that maintains the racial identity. He sees it as a breakthrough in mission if it can be applied in the churches among the young nations (see Du Plessis, 1960b:64).

\section{- The barriers must be crossed, but not abolished}

With the religious development of ecumenicity and independence, Du Plessis came to terms with the fact that mission has to do with the crossing of the frontiers, but without abolishing them. He stated this because he came to the conclusion that unity of believers across boundaries of colour and nationality is unavoidable, it can be seen as a cord binding humanity together in the darkness of this world (see Du Plessis, 1960b:63, 65). 


\section{- An African to Africans principle must be practised}

With his sympathetic approach, Du Plessis maintained that the principle of a "Bantu to a Bantu" be practised in mission fields. This principle helps the missionary to get to the bottom of issues surrounding the worldview of the people where mission is being done (Du Plessis, 1957:73).

Du Plessis should be applauded for having introduced this Biblical principle of contextualisation in his contribution towards the relevant reformed mission and missiology. Without compromising the content of the gospel message, Paul also became all things to all men in order to win them for Christ. To the Jews he became as a Jew, to the gentiles he became as a Gentile (1 Cor. 9:19-23). This principle is still very much relevant in the 21 st century. In this way the church in mission will do everything possible not to offend the recipients of the gospel (1 Cor. 10:32; Kane, 1976:84).

\section{- Physical needs of the objects of mission must be attended to}

The spiritual and physical needs of the objects of mission should be identified and addressed. When the proclaimed gospel addresses the spiritual need of fallen humanity, it should also identify and address the physical needs of the world. Du Plessis is of the opinion that: "Christianity is also called upon to awaken the conscience of the world to the needs within it - teeming hungry masses; despairing, struggling demoralised, beings in many parts of the world" (Du Plessis, 1960b:65).

\section{Conclusion}

The discussion above affirms the fact that Du Plessis was a child of his time. He lived and worked as a missionary and missiologist of the Reformed Churches in South Africa (GKSA) during the twentieth century. This was a time in which many things were happening within the ecumenical circles with regard to mission and missiology. What is striking is that Du Plessis was a person who participated meaningfully in the theological debates of his time. It is clear from the above discussion that Du Plessis' theology of mission was informed and shaped by the ecumenical debates of his time. 


\section{List of references}

ANDERSON, G.H. 1961. The theology of mission among protestants in the twentieth century. (In Anderson, G.H. The theology of the Christian mission. London: SCM. p. 3-16.)

ANDERSON, W. 1956. Towards a theology of mission. London: SCM.

BASSHAM, R.C. 1979. Mission theology: 1948-1975 years of worldwide creative tension, ecumenical, evangelical and Roman Catholic. Calfornia: William Carey Library.

BAVINCK, J.H. 1960. An introduction to the science of missions. New Jersey: $P$ \& R Publishing.

BEYERHAUS, P. 1971. Mission and humanization. (In Potter, P. International review of mission. London: Edinburgh. p. 11-24.)

$\mathrm{BOSCH}$, D.J. 1992. Transforming mission: paradigm shifts in theology of mission. Maryknoll: Orbis Books.

$\mathrm{BOSCH}$, D.J. 1993. Witness to the world: the Christian mission in theological perspective. Atlanta: John Knox Press.

COETZEE, J.C. 1997. Hermeneutics and exegesis of the New Testament. Potchefstroom: EFJS Drukkers.

DE KLERK, P.J.S. 1923. Kerk en sending in Suid-Afrika. Amsterdam: Bottenburg.

DENKEMA, F. 1995. God's missionary people. Potchefstroom: PU for CHE. (Reader for SEW 502/3.)

DU PLESSIS, H. 1942. 'n Getuienis vir al die nasies: ons sendingarbeid. Potchefstroom: Pro Rege.

DU PLESSIS, H. 1957. Rasseverhoudinge tussen blankes en naturelle. Die Kerkblad, 59(1359):53-88.

DU PLESSIS, H. 1959. Die kerk - 'n sendingkerk. (In Van der Merwe, D.C.S. \& Van der Walt, I.J. Gaan dan heen: 'n keur uit die geskrifte van wyle prof. $\mathrm{H}$. du Plessis, sy lewe en werk. Potchefstroom: Pro Rege. p. 173-175.)

DU PLESSIS, H. 1960a. Geskiedenis van die sendingwetenskap. Potchefstroom: Pro Rege.

DU PLESSIS, H. 1960b. The new era and Christian calling regarding the Bantu in South Africa. (In Geyser, A.S., Marais, B.J. \& Du Plessis, H. Delayed action: an ecumenical witness from the Afrikaans speaking church Pretoria: NG Kerkboekhandel. p. 57-77.)

DU PLESSIS, 1963. 'n Banier van die volke. Potchefstroom: Pro Rege.

DU PLESSIS, H. 1965a. Die doel van die sending. (In Van der Merwe, D.C.S. \& Van der Walt, I.J. Gaan dan heen: 'n keur uit die geskrifte van wyle prof. H. du Plessis, sy lewe en werk. Potchefstroom: Pro Rege. p. 266-269.)

DU PLESSIS, H. 1965b. Kerkverband tot oor die nasionale grense. (In Van der Merwe, D.C.S. \& Van der Walt, I.J. Gaan dan heen: 'n keur uit die geskrifte van wyle prof. H. du Plessis, sy lewe en werk. Potchefstroom: Pro Rege. p. 230-245.)

DU PLESSIS, H. 1966. Sending en ontwikkeling in Afrika. Die Kerkblad, 69 (1871):13.

DU PLESSIS, H. 1969. Aansluiting by die heidense godsdiens. Die Oes, 1:1011.

DU PLESSIS, H. 1970. Geen sending sonder kerk en geen kerk sonder sending. Potchefstroom: Pro Rege. 
FREYTAG, W. 1950. The meaning and purpose of the Christian mission. International review of mission, 39:153-161.

FREYTAG, W. 1959. Sending met 'n blik op die einde. (In Bohren, R., Freytag, W. \& Vicedom, G. Sending, kerk en sakramente. Kaapstad: Genadendalse Drukkery. p. 146-156.)

GLASSER, A.F. 1983. Conciliar perspectives: the road to reconciliation. (In Glasser, A.F. \& McGavran, D.A. Contemporary theologies of mission. Grand Rapids: Baker. p. 82-99.)

GREENWAY, R.S. 1999. Go and make disciples: an introduction to Christian missions. New Jersey: P \& R Publishing.

HOEKENDIJK, J.C. 1950. The call to evangelism. International review of mission, 39:163-175.

HOEKSTRA, H.T. 1979. The World Council of Churches and the demise of evangelism. Illinois: Tyndale.

JOOSTE, J.P. 1976. Prof. Hugo du Plessis se werk as sendeling in NoordTransvaal, 1928-1950. (In Van der Merwe, D.C.S. \& Van der Walt, I.J. Gaan dan heen: 'n keur uit die geskrifte van wyle prof. H. du Plessis, sy lewe en werk. Potchefstroom: Pro Rege. p. 209-223.)

KANE, J.H. 1976. Christian missions in Biblical perspective. Michigan: Baker Book House.

KRITZINGER, J.J., MEIRING, P.G.J. \& SAAYMAN, W.A. 1984. You will be my witness. Pretoria: NG Kerkboekhandel.

MASHAU, T.D. 2004. Hugo du Plessis' contribution to the Reformed Churches' struggle for a relevant mission and missiology. Potchefstroom: North-West University. (Ph.D. thesis.)

MCGAVRAN, D.A. 1983. What is mission? (In Glasser, A.F. \& McGavran, D.A. Contemporary theologies of mission. Grand Rapids: Baker. p. 82-99.)

MEIRING, P.G.J. 1994. Mission - what? Goal and content of mission. (In Kritzinger, J.J. \& Meiring, P.G.J. \& Saayman, W.A. On being witnesses. Halfway House: Orion. p. 1-40.)

NEWBIGIN, L. 1978. The open secret: sketches for a missionary theology. Grand Rapids: Eerdmans.

ROSIN, H.H. 1972. Missio Dei. Leiden.

SAAYMAN, W.A. 1984. Unity and mission. Pretoria: Unisa.

VAN DEN BERG, J. 1956. Constrained by Jesus' love: an inquiry into the motives of the missionary awakening in Great Britain in the period between 1689 and 1815. Kampen: Kok.

VAN DER VYVER, G.C.P. 1958. Professor Dirk Postma, 1818-1898. Potchefstroom: Pro Rege.

VAN DER WALT, S.P. 1976. Prof. Hugo du Plessis in Potchefstroom. (In Van der Merwe, D.C.S. \& Van der Walt, I.J. Gaan dan heen: 'n keur uit die geskrifte van wyle prof. H. du Plessis, sy lewe en werk. Potchefstroom: Pro Rege. p. 47.)

WALLS, A. 1982. The Gospel as the prisoner and liberator of culture. Missionalia, 10(3):93-105. 


\section{Key concepts:}

Du Plessis, Hugo

ecumenical circles

mission

missiology

theology

\section{Kernbegrippe:}

Du Plessis, Hugo ekumeniese kringe missiologie sending teologie 